\title{
Depressive Expression and Anti-Depressive Protection in Adolescence: Stress, Positive Affect, Motivation and Self-Efficacy
}

\author{
Mats Lindahl ${ }^{1 *}$, Trevor Archer ${ }^{2,3}$ \\ ${ }^{1}$ Department of Chemistry and Biomedical Sciences, Linnaeus University, Kalmar, Sweden \\ ${ }^{2}$ Department of Psychology, University of Gothenburg, Gothenburg, Sweden \\ ${ }^{3}$ Department of Sport Science, Linnaeus University, Kalmar, Sweden \\ Email: "mats.lindahl@lnu.se
}

Received March $12^{\text {th }}, 2013$; revised April 14 $4^{\text {th }}, 2013$; accepted May $22^{\text {nd }}, 2013$

\begin{abstract}
Copyright (C) 2013 Mats Lindahl, Trevor Archer. This is an open access article distributed under the Creative Commons Attribution License, which permits unrestricted use, distribution, and reproduction in any medium, provided the original work is properly cited.
\end{abstract}

\begin{abstract}
The present study aims at identifying predisposing and protective factors for the purpose of showing their respective contribution and interaction for adolescents' stress disorders and depressive states, and to find key attributes for the identification of pupils at risk in a normal population of adolescents. The study was performed with 211 high-school pupils over a period of 18 months. The results are reported from the pupils participating in 4 consecutive administrations of the instruments $(\mathrm{N}=115)$. The following instruments were used: "Kutcher Adolescent Depression Scale", "Stress", "Helplessness", "Hopelessness", "Uppsala Sleep inventory", "Barratt's Impulsiveness Scale", "Positive Affect and Negative Affect Scale", "Life Orientation Test", "General Self-Efficacy", "Locus of Control", "Situational Intrinsic Motivational Scale". The Positive Affect and Negative Affect Scale were also used to categorize participants into four affective profiles: "self-fulfilling", high affective", "low affective" and "self-destructive". Linear regression analyses showed that situational depression (hopelessness) was predicted by depressive. Negative affect predicted stress, which in turn predicted general and situational depressiveness. General self-efficacy, positive affect and Identified regulation were found to be protective factors to both general and situational depressiveness. Depressiveness was found to be linked to the "self-destructive" affective personality type. "Negative affect" and distractiveness are suggested as markers for pupils at risk, whereas positive affect, self-efficacy and identified regulation appear to have protecting roles.
\end{abstract}

Keywords: Adolescent Depressiveness; Impulsivity; Negative Affect; Motivation; Self-Efficacy

\section{Introduction}

The prevalence of depressive symptoms among adolescents has seen a notable increase during the last two decades (Avenevoli, Knight, Kessler, \& Merikangas, 2008). Depression during adolescence is predictive for future depressive episodes by individuals (Lewinsohn, Allen, Seeley, \& Gotlib, 1999; Rutter, Kim-Cohen, \& Maughan, 2006; Solomon et al., 2000). Adolescents appear more vulnerable than adults, as indicated by their comparatively more pronounced proneness to suicidal behaviour as a result of depression (Cole, 1989; Foley, Goldston, Costello, \& Angold, 2006; Gould et al., 1998). Further differences between adults and adolescents include the concurrence of vulnerability factors. Adults are assumed to be more predisposed to depression by the number of different vulnerability factors present, as proposed by the "additive" approach (Abela \& Hankin 2008). However, the occurrence of depression among adolescents may instead be conceptualized effectively following the "weakest link" approach, i.e. the notion that predisposition for depression depends on the magnitude of one of the depressogenic inferential styles of self, causes, and consequences (Abela \& Sarin, 2002).

In addition to the serious problem with adolescent proneness

"Corresponding author. to suicide, depression in adolescence impacts also on academic performance (Heiligenstein \& Guenther, 1996) in a manner that may be described as learned helplessness (Seligman, 1975). In the context of educational performance (Diener \& Dweck, 1978), the notion of learned helplessness was used to describe young pupils' "situational depression", a reaction to stressful life events that brings on depressive symptoms, as a result of academic failure. Later, Abramson, Metalsky and Alloy (1989) reformulated a more general and cognitive model of depression as a form of learned hopelessness, in the sense that negative expectancy of future events is acquired. Learned hopelessness is dependent on helplessness insofar as it is expected that negative outcomes cannot be avoided since the situation is perceived as uncontrollable and cannot be altered.

\section{Depression and Stress in Adolescence}

There is notable increase in depressive mood from preadolescence to adolescence (Brown \& Siegel, 1988; Hankin et al., 1998), possibly an outcome of the cognitive-emotional development in children (e.g. Ushijima, Usami, Saito, Kodaira, \& Ikeda 2012). However, more accepted explanation is derived from consideration of the accumulation of stressful life events (SLE) (Abela \& Hankin, 2008). According to this notion, re- 
petitive experiences of helplessness produce hopelessness and are enhanced through depressogenic attributions, essentially the search for explanations (Alloy et al., 1999; Lewinsohn, Joiner Jr., \& Rohde, 2001). Social and academic demands at school are stressors to children and adolescents; school performance offers one of the main stressors for adolescents (Byrne, Davenport, \& Mazanov, 2007). Research has shown that even preadolescent pupils are at risk of succumbing to learned hopelessness as a result of academic failure (Dweck \& Wortman, 1982; Burhans \& Dweck, 1995). Severe stress reactions, seen as the increased tendencies towards activation of the hypothalamic-pituitary-adrenal (HPA) axis, are present already among preadolescent pupils (Lindahl, Theorell, \& Lindblad, 2005). Stressful events contribute to the development of helplessness and hopelessness leading to poor academic performance, which in turn may worsen symptoms of helplessness and hopelessness (Au, Watkins, Hattie, \& Alexander, 2009).

It has been proposed that the augmented prevalence of depression among adolescents, compared to preadolescents, may be attributed to sensitization (Morris, Ciesla, \& Garber, 2010). Adolescents, due to psychobiological potentiation effects, are more vulnerable to uncontrollable stressful situations and subsequently more predisposed for negative affect (Chorpita \& Barlow, 1998). Adverse childhood events provided stress sensitization in clinically depressed adolescents (LaRocque, 2011). Increased affective responsiveness towards stressors in adolescence has been suggested to be associated with adolescent brain development (Archer, Kostrzewa, Beninger, \& Palomo, 2010; Archer, 2011). Brain development during adolescence appears to be linked to adolescent impulsive behaviour (Crews \& Boettiger, 2009) as a risk factor for addiction and other related problems (Churchwell, Lopez-Larson, \& Yurgelun-Todd, 2011; White et al., 2011), especially when combined with low levels of positive affect (Colder \& Chassin, 1997). However, it seems that impulsivity decreases in normal populations (Steinberg et al., 2008) and that instead sensation-seeking appears as a better explanatory factor for adolescent risk-taking behaviour (Harden \& Tucker-Drob, 2011). Impulsivity rather appears associated with "externalizing behaviour" whereas depression is associated with "internalizing behaviour" among children and adolescents (Lahey et al. 2004). The former refers to problems that are manifested in outward behavior reflecting a child's negative reactions to his/her environment whereas the latter involve actions directed toward the self, including withdrawal, anxiety, fearfulness, and depression (Rapport, Denney, Chung, \& Hustace, 2001).

\section{Affective Personality and Stress}

Negative affect among individuals is another trait associated with both helplessness (Evans \& Stecker, 2004) and depression (Ebestuani, Okamura, Higa-McMillan, \& Chorpita, 2011, Luten, Ralph, \& Mineka, 1997; Watson, Clark, \& Carey, 1988a). This is consistent with the finding that positive affect is negatively associated with depression (Watson et al., 1988a). By combining high/low positive affect with high/low negative affect, four different types of affective personality have been described (Bood, Archer, \& Norlander, 2004; Norlander, Bood, \& Archer, 2002). Affective personality types with high negative affect have been shown to report a higher degree of stress and a lower degree of coping and control than those with high positive affect (Karlsson \& Archer, 2007; George \& Brief, 1992; Spector
\& O'Connell, 1994). Moreover, adolescents as well as adults with "Self-destructive" personality, i.e. high negative affect and low positive affect, typically report a higher degree of depresssion than the other personality types (Archer, Adrianson, Plancak, \& Karlsson, 2007). Negative affect has also been associated with pessimism (Marshall, Wortman, Kusulas, Hervig, \& Vickers Jr., 1992), an association linked to learned hopelessness depression, since pessimism implies negative expectancy on the future. Indeed, dispositional optimism has been shown to be negatively associated with depression (Scheier, Carver, \& Bridges, 1994) and positively associated with active coping strategies when confronted with stressful situations (Scheier, Weintraub, \& Carver, 1986, Aspinwall \& Taylor, 1992).

\section{Self-Efficacy and Motivation among Students}

Self-efficacy presents a cognitive capacity suggested to moderate stressful events and depression (Maciejewski, Prigerson, \& Mazure, 2000). Self-efficacy promotes positive expectations on handling future situations and engagement in learning activities (Bandura, 1977, 1997), and is negatively associated with depression among adolescents (Ehrenberg, Cox, \& Koopman, 1991). Among college students, academic self-efficacy and optimism are positively associated, whereas stress and optimism are negative associated (Chemers, Hu, \& Garcia, 2001). Positive outcome expectations in school are associated with self-efficacy (Hackett, Betz, Casas, \& Rocha-Singh, 1992), and an intervention with the purpose of preventing depressive symptoms by increasing students' general self-efficacy was shown to be effective (Pössel, Baldus, Horn, Groen, \& Hautzinger, 2005). Self-efficacy has also been proposed as a motivating factor (Zimmerman, 2000). Indeed, considering the possibility that self-efficacy supports an expectancy of positive outcome, it seems likely to sustain motivation (Eccles et al., 1983). Affect, i.e. positive affect, has also been shown to be important for sustaining motivation in terms of positive expectations and seeking involvement (Erez \& Isen, 2002). The description of positive affect together with the resulting motivetional behaviour coincides with definitions of intrinsic motivetion (Deci \& Ryan 1985). In Self-Determination Theory, three types of motivation are described: Intrinsic motivation (Autonomous), extrinsic motivation (Controlled) and Amotivation (Deci \& Ryan, 1985; 2008). Adolescent anxiety and distraction in the classroom is negatively associated with intrinsic motivation but positively associated with amotivation (Ratelle, Guay, Vallerand, Larose, \& Senécal, 2007). Amotivation in the classroom refers to a state in which individuals cannot perceive a relationship between their behavior and that behavior's subsequent outcome (Shen, Winqert, Li, Sun, \& Rukavina, 2010). Furthermore, high-school pupils' amotivation has been shown to be multidimensional in the sense that there are four main reasons for amotivation: pupils' ability beliefs, pupils' effort beliefs, what value is placed on academic tasks? and the characteristics of the academic tasks (Legault, Green-Demers, \& Pelletier, 2006). High-school pupils' amotivation has been shown to predict impulsiveness (Palomo, Beninger, Kostrzewa, \& Archer, 2008).

\section{Aims of the Study}

An understanding of potentially predisposing factors and their interaction with potentially protective factors may provide 
information regarding individuals at risk and possible interventions to avoid affective disorders. The purpose of this explorative study is to identify predisposing and protective factors thereby showing their respective contribution and interaction for adolescents' stress disorders and depressive states. For preventive purposes, it is attempted to point out key attributes for the identification of pupils at risk.

\section{Method}

\section{Participants}

The participants were high-school pupils from a small town (50.000 inhabitants) in the south of Sweden. Initially, a total of 211 pupils (154 girls and 57 boys), 17.1 years of age, participated. They were all recruited during their first year in highschool (year 10). The pupils were randomly recruited from the following 4 different Swedish national study programmes (ordered by decreasing emphasis on theoretical studies): Natural science programme (73); Art, music and drama programme (66); Child-care and recreation programme (48); Restaurant and food programme (24).

\section{Ethical Considerations}

The project was undertaken in cooperation with the school principal for the purpose of highlighting stress as a problem of concern for both teachers and pupils. The agreement included total anonymity and fluidity of results through discussion with teachers as well as the participating pupils after the second and fourth semester. The pupils were informed two months in advance about the data collection. Reassurances were made that pupils only should participate at their free will and could decline at any time. They were also informed that data were to be coded immediately after collection and the code kept safe to ensure their anonymity both during analysis and any presentation of results.

\section{Instruments}

Kutcher Adolescent Depression Scale (KADS-6). KADS-6 (LeBlanc, Almudevar, Brooks, \& Kutcher, 2002), in a Swedish translation, was used to measure depressive mood. The 6-item instrument consisted of statements concerning general feelings of sadness, somatic and cognitive stress, helplessness, hopelessness and thoughts of self-injury. Respondents answered on a 4-point scale: "hardly ever", "much of the time", "most of the time", "all the time". The internal consistency was .82 (Chronbach's $\alpha$ ).

Stress. Experiences of somatic stress reactions during examination tests in school (in Sweden small tests in every single subject occur with about 4-week intervals) were measured using an abbreviated version of a Swedish translation of SSESubjective Stress Experience (Lòpez-Ibor, 2002). Items (11) concerning somatic stress were chosen from SSE. They were modified to focus the school test situation and presented on a 7-point scale with endpoints described as "Does not apply to me at all" (1) or "Applies to me fully" (7). The internal consistency was found to be .92 (Chronbach's $\alpha$ ).

Helplessness and Hopelessness. Instruments for measuring Helplessness and Hopelessness in the school test situation were constructed through the adaptation of existing constructs derived from several articles (Evans \& Stecker, 2004; Boggiano et al., 1992; Ursin \& Eriksen, 2004). Both instruments were presented on a 7-point scale with endpoints described as "Does not apply to me at all" (1) or "Applies to me fully" (7). The helplessness scale included 9 items (Chronbach $\alpha=.92$ ), i.e. "I get the feeling I want to give up when I encounter a really difficult question on a test". The hopelessness scale included 3 items (Chronbach $\alpha=.77$ ), i.e. "When I fail on a test I usually think of myself as a worthless person" (cf. Abramson, Seligman, \& Teasdale 1978).

Uppsala Sleep Inventory (USI). 17 items from the USI scale (Hetta et al., 1985) were used to measure two factors: Difficulties to sleep and Difficulties to fall asleep. Difficulties to sleep, a 7-item construct including potential problems of getting sufficient sleep, was presented on a 5-point scale ranging from "none" to "very big" (Chronbach's $\alpha=.78$ ). Difficulties to fall asleep, was a 10-item construct consisting of a variety of symptoms of stress considered to cause difficulties to fall asleep. They were presented on a 5-point scale ranging from "never" to "very often" (Chronbach's $\alpha=.82)$.

Barratt's Impulsiveness Scale (BIS-11, modified). This modified, Swedish version BIS-11 instrument consisted of 25 of the 30 BIS-11 items (Patton et al., 1995). In order to measure impulsivity, participants were asked to estimate how the 25 statements fit him/her as an individual on a 5-point scale (from "not at all" to "precisely"). The items were, according to Patton, Stanford and Barratt (1995), divided into three factors: Distractiveness (originally called Attentional impulsiveness) with Chronbach's $\alpha=.81$ ( 8 items); Non-planning impulsiveness with a Chronbach's $\alpha=.72$ ( 8 items); and Motor impulsiveness, comprising 9 items (Chronbach's $\alpha=.67$ ).

Positive affect and negative affect scale (PANAS). The PANAS-instrument provides a self-estimation of "affect", both positive and negative. It consists of 10 adjectives for the Negative Affect (NA) dimension (Negative affect: Chronbach's $\alpha$ $=.83$ ) and 10 adjectives for the Positive Affect (PA) dimension (Positive affect: Chronbach's $\alpha=.88$ ). The adjectives describe feelings (affect) according to Watson, Clark and Tellegen (1988b). Respondents give their estimates on a 5-point scale (from "not at all" to "very much"). Previous studies (Bood et al., 2004; Norlander et al., 2002) have modified and developed the PANAS instrument further through a subject-response based derivation of four types of affective personality. Following their procedure the PA-scale was divided into two parts to enable grouping participants into "high PA" and "low PA" (cut-off point $=53.2 \%$ ). A similar procedure was applied on the NAscale, enabling the formation of "high NA" and "low NA" (cut-off point $=48.9 \%$ ). Participants could then be assigned to one of four affective personality groups combined as follows: Self-Fulfilling (high PA and low NA); High Affective (high PA and high NA); Low Affective (low PA and low NA); and Self-Destructive (low PA and high NA).

Life orientation Test (LOT). This instrument measures individual's degree of dispositional optimism. The instrument is based on a general model, regarding self-regulated behaviour, which indicates that optimism exerts meaningful behavioural consequences based on the model (Norlander \& Archer, 2002). The instrument consists of 12 statements on a 5-point scale (from "strongly disagree" to "strongly agree"). When this instrument was used in this study the internal consistency was found to be .73 (Chronbach's $\alpha$ ).

General Self-Efficacy (GES). General Self-Efficacy (Koskinen-Hagman, Schwarzer, \& Jerusalem, 1999) is a 10-item in- 
strument measuring self-efficacy in the sense that the respondent can relate their self-efficacy to all or any situation (Chronbach's $\alpha=.88$ ). The statements are presented on a 4point scale ranging from "I totally disagree" to "I totally agree".

Locus of Control. This is a modified version according to Millet and Sandberg (2003), using an abbreviated version of Rotter scale (Rotter, 1966), developed for use in Swedish work settings. The score from four of the 8 items (on a 5-point scale) was reversed to enable recalculation to represent External locus of control (Chronbach's $\alpha=.70)$.

Situational Intrinsic Motivational Scale (SIMS). The SIMS instrument provides an estimation of the constructs (factors), intrinsic motivation, identified regulation, external regulation and amotivation (cf. Deci \& Ryan, 1985, 1991). The version used in this study include four items for each factor, modified to relate to the school setting, e.g. intrinsic motivation: "Because I think this attending school is interesting", identified regulation: "Because doing schoolwork is for my own good", external regulation: "Because I am supposed to do it", and amotivation: "I go to school but I am not sure it is worth it". The statements were responded to on a 7-point scale out of which 3 points were specified: 1) does not apply to me at all; 4) between applicable/ non-applicable; 7) applies to me exactly. The internal consistency (Chronbach's $\alpha$ ) for the four factors were: .85 (Intrinsic motivation); .71 (Identified regulation); .77 (External regulation), and .86 (Amotivation).

\section{Procedure}

Data were collected at four occasions with 6 months intervals, starting in the middle of the students' second (spring) term at high school. Data collection was done with one class (24 - 30 pupils) at a time, during a weekly scheduled meeting with their class teacher. The instruments were administrated by one of the authors and the pupils were encouraged to ask questions in the case any item appeared unclear. Out of the initially 211 pupils, 114 attended at all (4) occasions for data collection.

\section{Statistical Analyses}

One-way ANOVA was used with Affective personality (Self-Destructive, High-Affective, Low-Affective and SelfFulfilling) as independent variable to demonstrate any signifycant differences between affective personality types with regard to depressive mood, vulnerability factors and protective factors (Table 1). Post hoc tests according to Bonferroni were performed for analyses exhibiting homogeniety of variance according to Levene. When homogeniety of variance according to Levene was not met, post hoc tests according to Games-Howell were performed. For these variables, Welch test of equality of means was used to assess any significant differences between groups.

General linear models for the four consecutive terms were

Table 1.

Personal attributes associated, or not, with the four affective personality types self-destructive, low-affective, high-affective and self-fulfilling.

\begin{tabular}{|c|c|c|c|c|}
\hline \multirow{2}{*}{ Variable } & \multicolumn{4}{|c|}{ Affective personality types } \\
\hline & $\begin{array}{c}\text { Self-destructive }(\mathrm{n}=31) \\
\text { M (SE) }\end{array}$ & $\begin{array}{c}\text { Low-affective }(n=21) \\
\text { M (SE) }\end{array}$ & $\begin{array}{c}\text { High-affective }(\mathrm{n}=23) \\
\text { M (SE) }\end{array}$ & $\begin{array}{c}\text { Self-fulfilling }(n=40) \\
\text { M (SE) }\end{array}$ \\
\hline Depressive $\operatorname{mood}^{*}(\mathrm{~F}=25.54)$ & $2.00^{\mathrm{abc}}(.46)$ & $1.47(.31)$ & $1.63^{\mathrm{a}}(.29)$ & $1.31(.25)$ \\
\hline $\operatorname{Stress}^{*}(\mathrm{~F}=18.55)$ & $2.75^{\text {ac }}(.96)$ & $1.70(.50)$ & $2.23(1.11)$ & $1.47(.30)$ \\
\hline Helplessness $^{*}(\mathrm{~F}=13.85)$ & $3.80^{\mathrm{a}}(1.16)$ & $2.93(1.15)$ & $2.92(1.13)$ & $2.27(.61)$ \\
\hline Hopelessness $^{*}(\mathrm{~F}=32.35)$ & $4.00^{\mathrm{abc}}(1.08)$ & $2.60(.89)$ & $2.90^{\mathrm{a}}(.96)$ & $1.98(.55)$ \\
\hline Difficult to sleep $(\mathrm{F}=5.61)$ & $2.82^{\mathrm{a}}(.59)$ & $2.58(.57)$ & $2.75(.60)$ & $2.28(.59)$ \\
\hline Difficult to fall asleep ${ }^{*}(\mathrm{~F}=11.37)$ & $2.24^{\mathrm{a}}(.53)$ & $1.88(.43)$ & $2.40^{\mathrm{a}}(.62)$ & $1.75(.39)$ \\
\hline Distractiveness $(\mathrm{F}=7.23)$ & $2.99^{\mathrm{a}}(.44)$ & $2.80(.45)$ & $2.85(.46)$ & $2.51(.46)$ \\
\hline Non-planning impulsivity $(\mathrm{F}=4.18)$ & $2.88^{\mathrm{a}}(.49)$ & $2.75(.42)$ & $2.69(.50)$ & $2.50(.42)$ \\
\hline Motor impulsivity $(\mathrm{F}=.59)$ & $2.64(.41)$ & $2.70(.46)$ & $2.78(.46)$ & $2.65(.43)$ \\
\hline Optimism $(\mathrm{F}=10.53)$ & $2.10^{\mathrm{a}}(.38)$ & $2.34(.31)$ & $2.37(.38)$ & $2.63(.47)$ \\
\hline Self-Efficacy $(\mathrm{F}=9.15)$ & $2.62^{\mathrm{a}}(.35)$ & $2.83(.31)$ & $2.89(.41)$ & $3.05(.33)$ \\
\hline External Locus of Control $(\mathrm{F}=1.03)$ & $2.80(.40)$ & $2.70(.26)$ & $2.76(.46)$ & $2.64(.45)$ \\
\hline Intrinsic motivation $(\mathrm{F}=6.27)$ & $3.33^{\mathrm{ab}}(1.15)$ & $3.76(.90)$ & $4.37(1.12)$ & $4.37(1.19)$ \\
\hline Identified regulation $(\mathrm{F}=4.36)$ & $5.30(.70)$ & $5.27(1.17)$ & $5.89(.81)$ & $5.85(.78)$ \\
\hline External regulation $(\mathrm{F}=3.63)$ & $5.05(1.13)$ & $4.88(1.12)$ & $4.52(1.16)$ & $4.17(1.29)$ \\
\hline Amotivation $(\mathrm{F}=5.56)$ & $2.31^{\mathrm{a}}(.95)$ & $2.15(.90)$ & $1.80(.85)$ & $1.55(.68)$ \\
\hline
\end{tabular}

Notes: $\mathrm{M}=$ mean; $\mathrm{SE}=$ Standard error; ${ }^{*}$ Homogeniety of variance according to Levene was not met. Welch test of equality of means revealed a significant difference be-

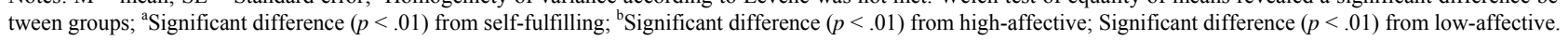


calculated to estimate the within-subject effects for each variable, in order to follow changes for the time-span of the investtigation. Although seven variables showed small but significant changes, the incongruent changes between terms gave little intelligible information about age and possible relationships between variables for the studied period of time. The small number of participants limited the possibilities to in detail study changes for selected groups of participants. Hence, data from all four occasions for data collection was pooled.

Stepwise linear regression calculations were performed with the pooled data and all latent variables using stress, helplessness, hopelessness, depressive mood and distractiveness as dependent variables. Although one-way ANOVA showed that girls reported significantly higher values for difficulties to fall asleep $[\mathrm{F}(1,113)=8.14, p<.05]$ and negative affect $[\mathrm{F}(1,60)=$ $8.95, p<.05]$ than boys, no differences regarding the order of predictors were found. Hence, the results reported here represents pooled data for both sexes.

\section{Results}

The data were collected initially for a longitudinal study of potential changes over the time-span of 1.5 high-school years. Over test occasions, a decrease was found for the following latent variables: negative affect $[\mathrm{F}(3,111)=4.62, p<.01]$; stress $[\mathrm{F}(3,111)=3.03, p<.05]$; helplessness $[\mathrm{F}(3,111)=3.37$, $p<.05]$. During the same period the following variables increased: distractiveness $[\mathrm{F}(3,111)=4.14, p<.01]$; dispositional optimism $[\mathrm{F}(3,111)=4.76, p<.01]$; general self-efficacy $[\mathrm{F}(3,111)=8.72, p<.001]$; and intrinsic motivation $[\mathrm{F}(3,111)$ $=3.26, p<.05]$.

\section{Affective Personalities}

With affective personality as independent variable in a one-way ANOVA, significant effects demonstrating differences in vulnerability between individuals having "Self-Destructive" affective personality was found. "Self-Destructive" individuals expressed significantly less dispositional optimism, general self-efficacy and intrinsic motivation compared to "Self-Fulfilling" individuals (see Table 1). They also expressed signifycantly more distractiveness, non-planning impulsivity, amotivation, stress, helplessness, hopelessness, depressive mood, difficulties to sleep and difficulties to fall asleep. The "SelfDestructive" pupils were demonstrated to present significantly more hopelessness and depressive mood than all other pupils.

\section{Linear Regression Analyses}

\section{Linear Regression Analyses Indicated That}

Stress was predicted by helplessness and negative affect, but counter predicted by amotivation $[\mathrm{F}(3,111)=60.53, p<.001$; adjusted $\left.\mathrm{R}^{2}=.61\right]$. Table 2 presents the regression analysis with Stress as dependent variable and Helplessness, General self-efficacy, External locus of control, Distractiveness, Motor impulsivity, Non-planning impulsivity, Intrinsic motivation, Identified regulation, External regulation, Amotivation, Dispositional optimism, Difficulties to sleep, Difficulties to fall asleep, Hopelessness, Depressive mood, Positive affect and Negative affect as independent variables.

Helplessness was predicted by hopelessness, distractiveness and stress, while counter predicted by identified regulation $\left[\mathrm{F}(4,110)=82.10, p<.001\right.$; adjusted $\left.\mathrm{R}^{2}=.74\right]$. Table 3 pre- sents the regression analysis with Helplessness as dependent variable and Stress, General self-efficacy, External locus of control, Distractiveness, Motor impulsivity, Non-planning impulsivity, Intrinsic motivation, Identified regulation, External regulation, Amotivation, Dispositional optimism, Difficulties to sleep, Difficulties to fall asleep, Hopelessness, Depressive mood, Positive affect and Negative affect as independent variables.

Hopelessness was predicted by helplessness, depressive mood and stress, but counter predicted by dispositional optimism, non-planning impulsivity and general self-efficacy $\left[\mathrm{F}(6,108)=61.68, p<.001\right.$; adjusted $\left.\mathrm{R}^{2}=.76\right]$. Table 4 presents the regression analysis with Hopelessness as dependent variable and Helplessness, Stress, General self-efficacy, External locus of control, Distractiveness, Motor impulsivity, Nonplanning impulsivity, Intrinsic motivation, Identified regulation, External regulation, Amotivation, Dispositional optimism, Difficulties to sleep, Difficulties to fall asleep, Depressive mood, Positive affect and Negative affect as independent variables.

Depressive mood was found to be predicted by negative affect and difficulties to sleep. And positive affect and motor impulsivity were counter predictors of depressive mood $\left[\mathrm{F}(4,110)=54.74, p<.001\right.$; adjusted $\left.\mathrm{R}^{2}=.69\right]$. Table 5 presents the regression analysis with Depressive mood as dependent variable and Helplessness, Stress, General self-efficacy, External locus of control, Distractiveness, Motor impulsivity,

Table 2.

Standardized weights from linear regression analysis with stress as dependent variable.

\begin{tabular}{cc}
\hline & \multicolumn{1}{c}{ Standardized beta } \\
\cline { 2 - 2 } Predictor variables & $(\beta)$ \\
\hline Helplessness & $.61^{* * *}$ \\
Negative affect & $.36^{* * *}$ \\
Amotivation & $-.18^{* *}$ \\
\hline
\end{tabular}

Note: ${ }^{* * *} p<.001,{ }^{* *} p<.01$; Predictor variables: General self-efficacy, External locus of control, Distractiveness, Motor impulsivity, Non-planning impulsivity, Intrinsic motivation, Identified regulation, External regulation, Dispositional optimism, Difficulties to sleep, Difficulties to fall asleep, Hopelessness, Depressive mood and Positive affect were non-significant.

Table 3.

Standardized weights from linear regression analysis with helplessness as dependent variable.

\begin{tabular}{|c|c|}
\hline \multirow{2}{*}{ Predictor variables } & Standardized beta \\
\hline & $(\beta)$ \\
\hline Stress & $.36^{* * *}$ \\
\hline Distractiveness & $.34^{* * *}$ \\
\hline Hopelessness & $.25^{* * *}$ \\
\hline Identified regulation & $-.18^{* *}$ \\
\hline $\begin{array}{l}\text { Note: }{ }^{* * *} p<.001,{ }^{* *} p<.01 ; \mathrm{Pr} \\
\text { locus of control, Motor impulsi } \\
\text { tion, External regulation, Amo } \\
\text { sleep, Difficulties to fall asleep } \\
\text { affect were non-significant. }\end{array}$ & $\begin{array}{l}\text { General self-efficac } \\
\text { impulsivity, Intrin } \\
\text { onal optimism, Dif } \\
\text {, Positive affect an }\end{array}$ \\
\hline
\end{tabular}


Table 4.

Standardized weights from linear regression analysis with hopelessness as dependent variable.

\begin{tabular}{cc}
\hline & Standardized beta \\
\cline { 2 - 2 } Predictor variables & $(\beta)$ \\
\hline Helplessness & $.32^{* * *}$ \\
Depressive mood & $.30^{* * *}$ \\
Dispositional optimism & $-.26^{* * *}$ \\
Non-planning impulsivity & $-.24^{* *}$ \\
General Self-Efficacy & $-.20^{* *}$ \\
Stress & $.20^{* *}$
\end{tabular}

Note: ${ }^{* * *} p<.001,{ }^{* *} p<.01$; Predictor variables: External locus of control, Distractiveness, Motor impulsivity, Intrinsic motivation, Identified regulation, External regulation, Amotivation, Difficulties to sleep, Difficulties to fall asleep, Positive affect and Negative affect were non-significant.

Table 5.

Standardized weights from linear regression analysis with depressive mood as dependent variable.

\begin{tabular}{cc}
\hline & Standardized beta \\
\cline { 2 - 2 } Predictor variables & $(\beta)$ \\
\hline Negative affect & $.50^{* * *}$ \\
Positive affect & $-.31^{* * *}$ \\
Difficulties to sleep & $.30^{* * *}$ \\
Motor impulsivity & $-.17^{* *}$
\end{tabular}

Note: ${ }^{* * *} p<.001,{ }^{* *} p<.01$; Predictor variables: Helplessness, Stress, General self-efficacy, External locus of control, Distractiveness, Non-planning impulsivity, Intrinsic motivation, Identified regulation, External regulation, Amotivation, Dispositional optimism, Difficulties to fall asleep and Hopelessness were nonsignificant.

Non-planning impulsivity, Intrinsic motivation, Identified regulation, External regulation, Amotivation, Dispositional optimism, Difficulties to sleep, Difficulties to fall asleep, Hopelessness, Positive affect and Negative affect as independent variables.

Distractiveness was predicted by helplessness, difficulties to sleep and motor impulsivity $[\mathrm{F}(3,111)=65.59, p<.001$; adjusted $\mathrm{R}^{2}=.63$ ]. Table 6 presents the regression analysis with Distractiveness as dependent variable and Helplessness, Stress, General self-efficacy, External locus of control, Motor impulsivity, Non-planning impulsivity, Intrinsic motivation, Identified regulation, External regulation, Amotivation, Dispositional optimism, Difficulties to sleep, Difficulties to fall asleep, Hopelessness, Depressive mood, Positive affect and Negative affect as independent variables.

\section{Discussion}

The primary purpose of the present study was to identify the factors that predispose and protect individuals, respectively, from stress disorders and depressive states, and the interaction between them. Thus, two basic notions are discussed that originate from this purpose: firstly, predisposing factors, and
Table 6.

Standardized weights from linear regression analysis with distractiveness as dependent variable.

\begin{tabular}{cc}
\hline & Standardized beta \\
\cline { 2 - 2 } Predictor variables & $(\beta)$ \\
\hline Helplessness & $.47^{* * *}$ \\
Difficulties to sleep & $.31^{* * *}$ \\
Motor impulsivity & $.23^{* * *}$ \\
\hline
\end{tabular}

Note: ${ }^{* * *} p<.001$; Predictor variables: Stress, General self-efficacy, External locus of control, Non-planning impulsivity, Intrinsic motivation, Identified regulation, External regulation, Amotivation, Dispositional optimism, Difficulties to fall asleep, Hopelessness, Depressive mood, Positive affect and Negative affect were non-significant.

secondly, protective factors. Predisposing factors included negative affect and distractiveness primarily, and stress, helplessness and hopelessness secondarily. Protective factors included: Positive affect, identified regulation and self-efficacy.

\section{Predisposing Factors}

The interplay between stress and depressive states is the fulcrum of the diathesis-model of depression. In this study of a healthy young population, helplessness and hopelessness in relation to examinations may be considered situational expressions of behaviour whereas depressive mood offers a more generalized expression. Hence, it may be reasoned that situational helplessness and hopelessness are more likely to impact upon each other than upon depression. The factors stress, helplessness and hopelessness are closely linked as they describe experiences in the examination situation. In this respect, they ought to be regarded as situational conditions, affective and consequential to unsuccessful attempts to cope with failure, implying a progressive learned helplessness ( $\mathrm{Au}$ et al., 2009; Burhans \& Dweck, 1995; Diener \& Dweck, 1978; Dweck \& Wortman, 1982). Although it may be hypothesized that stress may be aggravated by helplessness, it is not unreasonable to assume that stress precedes helplessness, which in turn precedes hopelessness (Au et al., 2009; Ursin \& Eriksen, 2004). The present results seem to follow the same reasoning since 1) stress and hopelessness are predictors of helplessness (Table 3) and 2) stress and helplessness are predictors of hopelessness (Table 4). Stress may be impelled by negative affect (Denollet $\&$ De Vries, 2006), which here is suggested to be a source of vulnerability, especially since negative affect may present a genetic attribute (Trzaskowski, Zavos, Haworth, Plomin, \& Eley, 2012). To further understand the assessed helplessness and hopelessness, they should be perceived as examples of socio-cognitive-emotional conditions and one expression of unsuccessful coping during exams (Abrahamson et al., 1989; Dweck \& Wortman, 1982; Hess \& Copeland, 2001).

It ought to be noted that while depressive mood promoted the "situational hopelessness" among the high-school pupils in the present investigation (Table 4), situational stress and learned helplessness or hopelessness had no impact on depressive mood. Hence, the vulnerability to situational hopelessness appears in the present circumstance to depend on one general predisposing factor: depressive mood; and on two situational predisposing factors: stress and helplessness. Although adolescent-related, 
the present results offer alternative notions to previous findings that negative expectancies of schoolwork, at least among college students, induce depression (Metalsky, Abramson, Seligman, Semmel, \& Peterson, 1982). They observed that students with an internal or global attributional style for negative outcomes at Time 1 experienced a depressive mood response when confronted with a subsequent low midterm grade, whereas students with an external or specific attributional style for negative outcomes were invulnerable to this depressive mood response.

In the present study, negative affect was found to be the main predisposing factor for depressive mood (Table 5). As expected, depressive mood was not only predicted by negative affect but also counter-predicted by positive affect (Luten et al., 1997; Watson et al., 1988b). In accordance with the diathesis-model, stressors, not accounted for here, that promote the depressive state since "difficulties to sleep" predicted depressive mood (Table 5) may be present. Sleeping difficulties may contribute an effect of stress, rather than a "true" (causal) predictor of depressive mood (Archer, Adolfsson, \& Karlsson, 2008). Negative affect is not only a predisposition for depressive mood, but also for stress during academic examinations. Indeed, negative affect is a predisposing factor for both stress reactions and helplessness. If one assumes that the experience of helplessness during examinations is more cognitive-emotionally oriented than the more biologically oriented stress reaction. Then, the predisposition for negative affect ought to exert a direct impact upon stress reactions but not on the experience of helplessness during examinations. Instead, helplessness appears to be mediated differently since distractiveness is a predictor for helplessness. Here, distractiveness may be interpreted as an example of avoidance and externalizing behaviour in a stressful situation (Lahey et al., 2004), reducing school performance but elevating risk of helplessness. Amotivation, another form of avoidance, predicted impulsiveness in several different studies (Archer \& Bright, 2012; Archer et al., 2008; Archer, Oscar-Berman, Blum, \& Gold, 2012; Palomo et al., 2008). Distractiveness, although possibly moderated by stress, presents a generalized condition prevalent in adolescence (Crews \& Boettiger, 2009; Lahey et al., 2004; Steinberg, Albert, Cauffman, Banich, Graham, \& Woolard, 2008). Hence, distractiveness presents not only a psychosomatic (Harden \& Tucker-Drob, 2011), but also a genetic attribute, which from the present results ought to predict and therewith promote situational helplessness. As a genetic attribute distractiveness has an impact on temperament, i.e. novelty-seeking, harm avoidance and reward dependence (Cloninger, Svrakic, \& Przybeck, 1993), and is likely to be modulated through childhood and adolescence as character is formed (Gillespie, Cloninger, Heath, \& Martina, 2003; Joyce et al., 2003). From the results in the present investigation it is suggested that stress accentuates distractive behaviour.

\section{Protective Factors}

General self-efficacy was a counter predictor for hopelessness in school test situations. Hence, self-efficacy is interpreted to have a protective effect against hopelessness. This is in line with the concept of self-efficacy (Bandura, 1977) and supported by research on college and university students (Chemers et al., 2001; Hackett et al., 1992). General self-efficacy has also been shown to prevent depressive symptoms (Pössel et al., 2005) and to promote positive expectations (Eccles et al., 1983; Erez \& Isen, 2002). Positive expectations are likely to counteract the emergence of any negative experiences following confrontation with failure. Hopelessness was also found to be moderated by dispositional optimism, a biological disposition that contributes to adaptive coping in inescapable and demanding situations (Scheier et al., 1986). Hence, both general self-efficacy and dispositional optimism are protective factors against hopelessness in school test situations.

Positive affect counteracts depressive mood in agreement with previous research (Watson et al., 1988a). What is more intriguing is the observation that motor impulsivity counterpredicts depressive mood, thus providing some protective effect. In view of the two suggested dimensions of motor impulsivity: functional and dysfunctional; such a notion is not unwarranted (Miller, Joseph, \& Tudway, 2004). Hence, the functional dimension of motor impulsivity, i.e. little worries in relation to acting in face of any risks being involved, can be interpreted to moderate depressive mood, especially since this study is on a normal population of high-school pupils.

Identified regulation was found to be a protective factor against situational helplessness. This may be understood in the sense that motivation to do school work reduces risks of encountering helplessness in test situations. It was surprising to find that amotivation also appeared to be a protective factor as it counter-predicts situational stress. Applying the notion of Self-Determination Theory (Deci \& Ryan, 1985), amotivation may be seen here as a type coping behaviour (albeit short-term) by reducing the value of the academic task (Legault et al., 2006). Hence, amotivation as a coping response, although an internalizing behaviour, offers a rather dysfunctional protection towards stress (Ratelle et al., 2007).

\section{Markers for Comparison with Previous Studies}

The notion that cognitive-affective domains such as depressive mood and impulsivity impact upon situational helplessness and hopelessness provides an avenue for understanding the vulnerability of adolescent pupils as they struggle through the educational system. Depressive mood, as demonstrated from the present findings, does impact upon situational hopelessness, whereas none of the situational stress reactions: stress, helplessness and hopelessness produced any impact on depressive mood. Hence, among these factors, only depressive mood may be considered to be a general predisposing factor. Following the weakest link approach notion (Abela \& Sarin, 2002), depressive mood appears to be the best general marker for situational hopelessness. However, helplessness may provide a situational marker for hopelessness and ought to be considered as a more suitable marker for interventional procedures in an educational practice. Situational stress emerges also as a marker for situational helplessness applicable in educational practice.

Negative affect was a predictor of depressive mood among the adolescents in this study. This is in contrast to a study on young adults, which show a lack of relation between depression and negative affect (Nima, 2012). This discrepancy may be related to differences in levels of brain maturation processes (Archer et al., 2010; Archer, 2011), possibly in concert with the selection occurring in the transition of pupils from high-school to university. Nevertheless, two studies applying Beck's Depression Inventory and the Hospital Anxiety and Depression test demonstrated the relationship between depressive expression and negative affect in young adults (Archer et al., 2008). Negative affect predicts stress, and following the reasoning of 
Ursin \& Ericsen (2004) whereby stress is the starting point for helplessness and hopelessness, negative affect emerges as the most reliable marker even for situational stress. Since negative affect offers a genetic attribute (Melke et al., 2003; Wei et al., 2012), it is here considered to be a key attribute for both depressive mood and situational stress. This notion is supported by the findings that the affective personality type "Self-Destructive" (high negative affect and low positive affect) individuals, who typically report high degrees of the factors predisposing for stress disorders, depressive mood states and dysfunctional coping, while showing low degrees of protective factors (Agerström, Möller, \& Archer, 2006; Andersson-Arntén, Jansson, \& Archer, 2007; Huemer et al., 2012; Karlsson \& Archer, 2007). Distractiveness is another genetic attribute (Coldren et al., 2009; Melke et al., 2003), which is accentuated when protective factors of cognitive nature are pealed off as a result of exposure to stressors. This association is demonstrated here by the prediction of situational helplessness by distractiveness in concert with stress.

\section{Strenghts and Limitations}

The study provides a relative straightforward description of predisposing and protective factors for depressive mood in adolescence. Nevertheless certain limitations ought to be indicated, including the high rate of attrition and the relatively small number of participants.

\section{Conclusion and Clinical Implications}

Identification of risk through negative affects and distractiveness attributes involves moderating and/or mediating factors, e.g. positive affect, self-efficacy and identified regulation. It is suggested that the interplay between predisposing and protective factors require consideration for developing strategies to help children and adolescents combat situational helplessness and hopelessness.

\section{Acknowledgements}

This study was supported by Faculty of Health, Social Work and Behavioural Sciences at Linnaeus University. We also wish to convey our gratitude to the participating pupils for lending their time to answer the questionnaires.

\section{REFERENCES}

Abela, J. R. Z., \& Sarin, S. (2002). Cognitive vulnerability to hopelessness depression: A chain is only as strong as its weakest link. Cognitive Therapy and Research, 26, 811-829. doi:10.1023/A:1021245618183

Abela, J. R. Z., \& Hankin, B. L. (2008). Cognitive vulnerability to depression in children and adolescents. A developmental psychopathology perspective. In: J. R. Z. Abela, \& B. L. Hankin (Eds.), Handbook of depression in children and adolescents (pp. 35-78). New York: Guilford Press.

Abramson, L. Y., Metalsky, G. I., \& Alloy, L. B. (1989). Hopelessness depression: A theory-based subtype of depression. Psychological Review, 96, 358-372. doi:10.1037/0033-295X.96.2.358

Abramson, L., Seligman, M., \& Teasdale, J. (1978). Learned helplessness in humans: Critique and reformulation. Journal of Abnormal Psychology, 87, 49-74. doi:10.1037/0021-843X.87.1.49

Agerström, J., Möller, K., \& Archer, T. (2006). Influence of affective personality and dilemma content on moral reasoning: Effect of gen- der. Social Behavior \& Personality, 34, 1259-1276. doi:10.2224/sbp.2006.34.10.1259

Alloy, L. B, Abramson, L. Y., Whitehouse, W. G., Hogan, M. E., Tashman, N. A., Steinberg, D. L., Rose, D. T., \& Donovan. P. (1999). Depressogenic cognitive styles: Predictive validity, information processing and personality characteristics, and developmental origins. Behaviour Research and Therapy, 37, 503-531. doi:10.1016/S0005-7967(98)00157-0

Andersson-Arntén, A. C., Jansson, B., \& Archer, T. (2007). Influence of affective personality type and gender upon coping behaviour, mood and stress. Individual Differences Research, 6, 139-168.

Archer, T. (2011). Effects of exogenous agents on brain development: Stress, abuse and therapeutic compounds. CNS Neuroscience \& Therapeutics, 17, 470-489. doi:10.1111/j.1755-5949.2010.00171.x

Archer, T., \& Bright, P. (2012). Functional and structural MRI studies on impulsiveness: Attention-deficit/hyperactive disorder and borderline personality disorder. In P. Bright (Ed.) Neuroimaging-Cognitive and clinical neuroscience (pp. 205-228). Rijeka: InTech.

Archer, T., Adolfsson, B., \& Karlsson, E. (2008). Affective personality as cognitive-emotional presymptom profiles regulatory for self-reported health predispositions. Neurotoxicity Research, 14, 21-44. doi:10.1007/BF03033573

Archer, T., Adrianson, L., Plancak, A., \& Karlsson, E. (2007). Influence of affective personality on cognition-mediated emotion processing: Need for empowerment. European Journal of Psychiatry, 21, 248-262. doi:10.4321/S0213-61632007000400002

Archer, T., Kostrzewa, R. M., Beninger, R. J., \& Palomo, T. (2008). Cognitive symptoms facilitatory for diagnoses in neuropsychiatric disorders: Executive functions and locus of control. Neurotoxicity Research, 14, 205-225. doi:10.1007/BF03033811

Archer, T., Oscar-Berman, M., Blum, K., \& Gold, M. (2012). Neurogenetics and epigenetics in impulsive behaviour: Impact on reward circuitry. Journal of Genetic Syndromes \& Gene Therapy, 3, 1-15. doi: $10.4172 / 2157-7412.1000115$

Archer, T., Kostrzewa, R. M., Beninger, R. J., \& Palomo, T. (2010). Staging perspectives in neurodevelopmental aspects of neuropsychiatry: Agents, phases and ages at expression. Neurotoxicity Research, 18, 287-305. doi:10.1007/s12640-010-9162-6

Aspinwall, L. G., \& Taylor, S. E. (1992). Modeling cognitive adaption: A longitudinal investigation of the impact of individual differences and coping on college adjustment and performance. Journal of Personality and Social Psychology, 63, 989-1003. doi:10.1037/0022-3514.63.6.989

Au, R. C. P., Watkins, D., Hattie, J., \& Alexander, P. (2009). Reformulating the depression model of learned hopelessness for academic outcomes. Educational Research Review, 4, 103-117. doi:10.1016/j.edurev.2009.04.001

Avenevoli, S., Knight, E., Kessler, R. C., \& Merikangas, K. R. (2008). Epidemiology of depression in children and adolescents. In: J. R. Z. Abela, \& B. L. Hankin (Eds.), Handbook of depression in children and adolescents (pp. 6-32). New York: Guilford Press.

Bandura, A. (1977). Self-efficacy: Toward a unifying theory of behavior change. Psychological Review, 84, 191-215. doi:10.1037/0033-295X.84.2.191

Bandura, A. (1997). Self-efficacy: The exercise of control. New York: Freeman.

Boggiano, A. K., Shields, A., Barrett, M., Kellam, T., Thompson, E., Simons, J., \& Katz, P. (1992). Helpless deficits in students: The role of motivational orientation. Motivation \& Emotion, 16, 271-296. doi:10.1007/BF00991655

Bood, S. A., Archer, T., \& Norlander, T. (2004). Affective personality in relation to general personality, self-reported stress, coping and optimism. Individual Differences Research, 2, 26-37.

Brown, J. D., \& Siegel, J. M. (1988). Attributions for negative life events and depression: The role of perceived control. Journal of Personality and Social Psychology, 54, 316-322. doi:10.1037/0022-3514.54.2.316

Byrne, D. G., Davenport, S. C., \& Mazanov, J. (2007). Profiles of adolescent stress: The development of the adolescent stress questionnaire (ASQ). Journal of Adolescence, 30, 393-416. 
doi:10.1016/j.adolescence.2006.04.004

Chemers, M. M., Hu, L., \& Garcia, B. F. (2001). Academic self-efficacy and first-year college student performance and adjustment. Journal of Educational Psychology, 93, 55-64. doi:10.1037/0022-0663.93.1.55

Chorpita, B. F., \& Barlow, D. H. (1998). The development of anxiety: The role of control in early environment. Psychological Bulletin, 124, 3-21. doi:10.1037/0033-2909.124.1.3

Churchwell, J. C., Lopez-Larson, M., \& Yurgelun-Todd, D. A. (2010). Altered frontal cortical volume and decision making in adolescent cannabis users. Frontiers in Psychology, 1, 225. doi:10.3389/fpsyg.2010.00225

Cloninger, C. R., Svrakic, D. M., \& Przybeck, T. R. (1993). A psychobiological model of temperament and character. Archives of General Psychiatry, 50, 975-990. doi:10.1001/archpsyc.1993.01820240059008

Colder, C. R., \& Chassin, L. (1997). Affectivity and impulsivity: Temperament risk for adolescent alcohol involvement. Psychology of Addictive Behaviors, 11, 83-97. doi:10.1037/0893-164X.11.2.83

Coldren, C. D., Lai, Z., Shragg, P., Rossi, E., Glidewell, S. C., Zuffardi, O., Mattina, T., Ivy, D. D., Curfs, L. M., Mattson, S. N., Riley, E. P., Treier, M., \& Grossfeld, P. D. (2009). Chromosomal microarray mapping suggests a role for BSX and Neurogranin in neurocognitive and behavioural defects in the 11q terminal deletion disorder (Jacobsen syndrome). Neurogenetics, 10, 89-95.

doi:10.1007/s10048-008-0157-x

Cole, D. (1989). Psychopathology of adolescent suicide: Hopelessness, coping beliefs, and depression. Journal of Abnormal Psychology, 98, 248-255. doi:10.1037/0021-843X.98.3.248

Crews, F. T., \& Boettiger, C. A. (2009). Impulsivity, frontal lobes and risk for addiction. Pharmacology, Biochemistry and Behavior, 93, 237-247. doi:10.1016/j.pbb.2009.04.018

Deci, E. L., \& Ryan, R. M. (1985). Intrinsic motivation and self-determination in human behavior. New York: Plenum.

Deci, E. L., \& Ryan, R. M. (1991). A motivational approach to self: integration in personality. In: R. Dienstbier (Ed.), Nebraska symposium on motivation: Vol. 38. Perspectives on motivation (pp 237288). Lincoln, NE: University of Nebraska Press.

Deci, E. L., \& Ryan, R. M. (2008). Self-determination theory: A macrotheory of human motivation, development, and health. Canadian Psychology, 49, 182-185. doi:10.1037/a0012801

Denollet, J., \& De Vries, J. (2006). Positive and negative affect within the realm of depression, stress and fatigue: The two-factor distress model of the Global Mood Scale (GMS). Journal of Affective Disorders, 91, 171-180. doi:10.1016/j.jad.2005.12.044

Diener, C. I., \& Dweck, C. S. (1978). An analysis of learned helplessness: Continuous changes performance, strategy, and achievement cognitions following failure. Journal of Personality and Social Psychology, 36, 451-462. doi:10.1037/0022-3514.36.5.451

Dweck, C. S., \& Wortman, C. B. (1982). Learned helplessness, anxiety, and achievement motivation: Neglected parallels in cognitive, affective, and coping response. In H. W. Krohne, \& L. Laux (Eds.), Achievement, stress, and anxiety (pp. 93-125). New York: Academic Press.

Ebestuani, C., Okamura, K., Higa-McMillan, C., \& Chorpita, B. F. (2011). A psychometric analysis of the positive and negative affect schedule for children-parent version in a school sample. Psychological Assessment, 23, 406-416. doi:10.1037/a0022057

Eccles, J. S., Adler, T. F., Futterman, R., Goff, S. B., Kaczala, C. M., \& Meece, J. (1983). Expectancies, values and academic bahavoirs. In J. T. Spence (Ed.), Achievement and achievement motives (pp. 75-146). San Fransisco, CA: W. H. Freeman.

Ehrenberg, M. F., Cox, D. N., \& Koopman, R. F. (1991). The relationship between self-efficacy and depression in adolescents. Adolescence, 26, 361-374.

Erez, A., \& Isen, A. M. (2002). The influence of positive affect on the components of expectancy motivation. Journal of Applied Psychology, 87, 1055-1067. doi:10.1037/0021-9010.87.6.1055

Evans, G. W., \& Stecker, R. (2004). Motivational consequences of environmental stress. Journal of Environmental Psychology, 24, 143-
165. doi:10.1016/S0272-4944(03)00076-8

Foley, D. L., Goldston, D. B., Costello, E., \& Angold, A. (2006). Proximal psychiatric risk factors for suicidal thoughts and behaviors in youth: The great smoky mountains study. Archives of General Psychiatry, 63, 1017-1024. doi:10.1001/archpsyc.63.9.1017

George, J. M., \& Brief, A. P. (1992). Feeling good-doing good: A conceptual analysis of the mood at work-organizational spontaneity relationship. Psychological Bulletin, 112, 310-329.

doi:10.1037/0033-2909.112.2.310

Gillespie, N. A., Cloninger, C. R., Heath, A. C., \& Martina, N. G. (2003). The genetic and environmental relationship between Cloninger's dimensions of temperament and character. Personality and Individual Differences, 35, 1931-1946. doi:10.1016/S0191-8869(03)00042-4

Gould, M. S., King, R., Greenwald, S., Fisher, P., Schwab-Stone, M., Kramer, R., Flisher, A. J, Goodman, S., Canino, G., \& Shaffer D. (1998). Psychopathology assoiciated with suicidal ideation and attempts among children and adolescents. Journal of the American Academy of Child \& Adolescent Psychiatry, 37, 915-923.

doi:10.1097/00004583-199809000-00011

Hackett, G., Betz, N. E., Casas, J. M., \& Rocha-Singh, I. A. (1992). Gender, ethnicity, and social cognitive factors predicting the academic achievement of students in engineering. Journal of Counseling Psychology, 39, 527-538. doi:10.1037/0022-0167.39.4.527

Hankin, B. L., Abramson, L. Y., Moffitt, T. E., Silva, P. A., McGee, R., \& Angell, K. E. (1998). Development of depression from preadolecence to young adulthood: Emerging gender differences in a 10-year longitudinal study. Journal of Abnormal Psychology, 107, 128-140. doi:10.1037/0021-843X.107.1.128

Harden, K. P., \& Tucher-Drob, E. M. (2011). Individual differences in the development of sensation seeking and impulsivity during adolescence: Further evidence for a dual systems model. Developmental Psychology, 47, 739-746. doi:10.1037/a0023279

Heiligenstein, E., \& Guenther, G. (1996). Depression and academic impairment in college students. Journal of American College Health, 45, 59-64. doi:10.1080/07448481.1996.9936863

Hetta, J., Almqvist, M., Ågren, H., Hambert, G., Liljenberg, G. B., \& Roos, B. E. (1985). Prevalence of sleep disturbances and related symptoms in a middle-aged Swedish population. In W. P. Koella, E. Ruther, \& H. Schultz (Eds.), Sleep, 84 (pp. 373-376). Stuttgart: Gustaf Fischer Förlag.

Huemer, J., Völkl-Kernstock, S., Karnik, N. G., Denny, K., Granditsch, E., Mitterer, M., Humphreys, K., Plattner, B., Friedrich, M., Shaw, R. J., \& Steiner, H. (2012). Personality and psychopathology in African unaccompanied refugee minors: Repression, resilience and vulnerability. Child Psychiatry and Human Development, 44, 39-50.

Joyce, P. R., McKenzie, J. M., Luty, S. E., Mulder, R. T., Caner, J. D., Sullivan, P. F., \& Cloninger, C. R. (2003). Temperament, childhood environment and psychopathology as risk factors for avoidant and borderline personality disorders. Australian and New Zealand Journal of Psychiatry, 37, 756-764. doi:10.1111/j.1440-1614.2003.01263.x

Karlsson, E., \& Archer, T. (2007). Relationship between personality characteristics and affect: Gender and affective personality. Individual Differences Research, 5, 44-58.

Koskinen-Hagman, M., Schwarzer, R., \& Jerusalem, M. (1999). Swedish version of the general self-efficacy scale. http://userpage.fu-berlin.de/ health/swedish.htm

Lahley, B. B., Applegate, B., Waldman, I. D., Loft, J. D., Hankin, B. L., \& Rick, J. (2004). The structure of child and adolescent psychopathology: Generating new hypotheses. Journal of Abnormal Psychology, 113, 358-385. doi:10.1037/0021-843X.113.3.358

LaRocque, C. L. (2011). Childhood maltreatment and stress sensitization in depression: Moderation by age group and depression history. Master's Thesis, Kingston: Queen's University.

LeBlanc, J. C., Almudevar, A., Brooks, S. J., \& Kutcher, S. (2002). Screening for adolescent depression comparison of the Kutcher Adolescent Depression Scale with the Beck Depression Inventory. Psychopharmacology, 12, 113-126.

Legault, L., Green-Demers, I., \& Pelletier, L. (2006). Why do high 
school students lack motivation in the classroom? Toward an understanding of academic amotivation and the role of social support. Journal of Educational Psychology, 98, 567-582. doi:10.1037/0022-0663.98.3.567

Lewinsohn, P. M., Allen, N. B., Seeley, J. R., \& Gotlib, I. H. (1999). First onset versus recurrence of depression: Differential processes of psychosocial risk. Journal of Abnormal Psychology, 108, 483-489. doi:10.1037/0021-843X.108.3.483

Lewinsohn, P. M., Joiner Jr., T. E., \& Rohde, P. (2001). Evaluation of cognitive diathesis-stress models in predicting major depressive disorder in adolescents. Journal of Abnormal Psychology, 110, 203-215. doi:10.1037/0021-843X.110.2.203

Lindahl, M., Theorell, T., \& Lindblad, F. (2005). Test performance and self-esteem in relation to experienced stress in Swedish sixth and ninth graders-saliva cortisol levels and physiological reactions to demands. Acta Paediatrica, 94, 489-495. doi:10.1111/j.1651-2227.2005.tb01922.x

Lòpez-Ibor, J. J. (2002). The classification of stressrelated disorders in ICD-10 and DSM-IV. Psychopathology, 35, 107-111. doi:10.1159/000065128

Luten, A. G., Ralph, J. A., \& Mineka, S. (1997). Pessimistic attributional style: is it specific to depression versus anxiety versus negative affect? Behavioral Research and Therapy, 35, 703-719. doi:10.1016/S0005-7967(97)00027-2

Maciejewski, P. K., Prigerson, H. G., \& Mazure, C. M. (2000). Selfefficacy as a mediator between stressful life events and depressive symptoms. Differences based on history of prior depression. British Journal of Psychiatry, 176, 373-378. doi:10.1192/bjp.176.4.373

Marshall, G. N., Wortman, C., Kusulas, J. W., Hervig, L. K., \& Vickers Jr., R. R. (1992). Distinguishing optimism from pessimism: Relations to fundamental dimensions of mood and personality. Journal of Personality and Social Psychology, 62, 1067-1074.

doi: $10.1037 / 0022-3514.62 .6 .1067$

Maier, S. F., \& Seligman, M. E. P. (1976). Learned helplessness: Theory and evidence. Journal of Experimental Psychology: General, 105, 3-46. doi:10.1037/0096-3445.105.1.3

Melke, J., Westberg, L., Nilsson, S., Landén, M., Soderstrom, H., Baghaei, F., Rosmond, R., Holm, G., Björntorp, P., Nilsson, L.-G., Adolfsson, R., \& Eriksson, E. (2003). A polymorphism in the serotonin receptor $3 \mathrm{~A}$ (HTR3A) gene and its association with harm avoidance in women. Archives of Genetic Psychiatry, 60, 1017-1023. doi:10.1001/archpsyc.60.10.1017

Metalsky, G. I., Abramson, L. Y., Seligman, M. E. P., Semmel, A., \& Peterson, C. R. (1982). Attributional styles and life events in the classroom: Vulnerability and invulnerability to depressive mood reactions. Journal of Personality and Social Psychology, 43, 612-617. doi:10.1037/0022-3514.43.3.612

Miller, E., Joseph, S., \& Tudway, J. (2004). Assessing the component structure of four self-report measures of impulsivity. Personality and Individual Differences, 37, 349-358. doi:10.1016/j.paid.2003.09.008

Millet, P. \& Sandberg, K. (2003). Locus of control and its relationship with rehabilitation outcomes of unemployed sick leavers in Sweden. Journal of Vocational Rehabilitation, 19, 59-66.

Morris, M. C., Ciesla, J. A., \& Garber, J. (2010) A prospective study of stress autonomy versus stress sensitization in adolescents at varied risk for depression. Journal of Abnormal Psychology, 119, 341-354. doi: $10.1037 / \mathrm{a} 0019036$

Nima, A. A. (2012). Mediational and moderating effects influencing depressiveness experienced among students: Anxiety, stress, self-esteem and affective personality. Master Thesis, Gothenburg: Gothenburg University.

Norlander, T. \& Archer, T. (2002). Prediction performance in ski and swim championships: Effectiveness of mood, perceived exertion, and dispositional optimism. Perceptual and Motor Skills, 94, 153-164. doi: 10.2466/pms.2002.94.1.153

Norlander, T., Bood, S. Å., \& Archer, T. (2002). Performance during stress: Affective personality, age and regularity of physical exercise. Social Behavior and Personality, 30, 495-508.

doi:10.2224/sbp.2002.30.5.495
Palomo, T., Beninger, R. J., Kostrzewa, R. M., \& Archer, T. (2008). Focusing on symptoms rather than diagnoses in brain dysfunction: Conscious and nonconscious expression in impulsiveness and decision-making. Neurotoxicity Research, 14, 1-20. doi:10.1007/BF03033572

Patton, J. D. A., Stanford, M. S., \& Barratt, E. S. (1995). Factor structure of the barratt impulsive scale. Journal of Clinical Psychology, $51,768-774$.

doi:10.1002/1097-4679(199511)51:6<768::AID-JCLP2270510607> 3.0.CO;2-1

Pössel, P., Baldus, C., Horn, A. B., Groen, G., \& Hautzinger, M. (2005). Influence of general self-efficacy on the effects of a school-based universal primary prevention program of depressive symptoms in adolescents: A randomized and controlled follow-up study. Journal of Child Psychology and Psychiatry, 46, 982-994. doi:10.1111/j.1469-7610.2004.00395.x

Ratelle, C. F., Guay, F., Vallerand, R. J., Larose, S., \& Senécal, C. (2007). Autonomous, controlled, and amotivated types of academic motivation: A person-oriented analysis. Journal of Educational Psychology, 99, 734-746. doi:10.1037/0022-0663.99.4.734

Rapport, M. D., Denney, C. B., Chung, K. M., \& Hustace, K. (2001). Internalizing behavior problems and scholastic achievement in children: Cognitive and behavioral pathways as mediators of outcome. Journal of Clinical Child Psychology, 30, 536-551. doi:10.1207/S15374424JCCP3004 10

Rotter, J. B. (1966). Generalized expectancies for Internal versus External Control of Locus of Reinforcement. Psychological Monographs, 80, 1-28. doi:10.1037/h0092976

Rutter, M., Kim-Cohen, J., \& Maughan, B. (2006). Continuities and discontinuities in psychopathology between childhood and adult life. Journal of Child Psychology and Psychiatry, 47, 276-295. doi:10.1111/j.1469-7610.2006.01614.x

Scheier, M. F., Carver, C. S., \& Bridges, M. W. (1994). Distinguishing optimism from neuroticism (and trait anxiety, self-mastery, and self-esteem): A reevaluation of the life orientation test. Journal of Personality and Social Psychology, 67, 1063-1078. doi:10.1037/0022-3514.67.6.1063

Scheier, M. F., Weintraub, J. K., \& Carver, C. S. (1986). Coping with stress: Divergent strategies of optimists and pessimists. Journal of Personality and Social Psychology, 51, 1257-1264. doi:10.1037/0022-3514.51.6.1257

Schwarzer, R., Schmitz, G. S., \& Tang, C. (2000). Teacher burnout in Hong Kong and Germany: A cross-cultural validation of the Maslach Burnout Inventory. Anxiety, Stress and Coping, 13, 309-326.

Seligman, M. E. P. (1975). Helplessness: On depression, development, and death. San Francisco, CA: Freeman.

Shen, B., Winqert, R. K., Li, W., Sun, H., \& Rukavina, B. K. (2010). An amotivational model in physical education. Journal of Teaching in Physics Education, 29, 72-84.

Solomon, D. A., Keller, M. B., Leon, A. C., Mueller, T. I., Lavori, P. W., Shea, M. T., Coryell, W., Warshaw, M., Turvey, C., Maser, J. D., \& Endicott, J. (2000). Multiple recurrences of major depressive disorder. American Journal of Psychiatry, 157, 229-233. doi:10.1176/appi.ajp.157.2.229

Spector, P. E., \& O’Connell, B. J. (1994). The contribution of personality traits, negative affectivity, locus of control and Type A to the subsequent reports of job stressors and job strains. Journal of Occupational and Organizational Psychology, 67, 1-12. doi:10.1111/j.2044-8325.1994.tb00545.x

Steinberg, L., Albert, D., Cauffman, E., Banich, M., Graham, S., \& Woolard, J. (2008). Age differences in sensation seeking and impulsivity as indexed by behavior and self-report: Evidence for a dual systems model. Developmental Psychology, 44, 1764-1778. doi:10.1037/a0012955

Trzaskowski, M., Zavos, H. M. S., Haworth, C. M. A., Plomin, R., \& Eley, T. C. (2012). Stable genetic influence on anxiety-related behaviours across middle childhood. Journal of Abnormal Child Psychology, 40, 85-94. doi:10.1007/s10802-011-9545-z

Ursin, H., \& Eriksen, H. R. (2004). The cognitive activation theory of stress. Psychoneuroendocrinology, 29, 567-592. 
doi:10.1016/S0306-4530(03)00091-X

Ushijima, H., Usami, M., Saito, K., Kodaira, M., \& Ikeda, M. (2012). Time course of the development of depressive mood and oppositional defiant behavior among boys with attention deficit hyperactivity disorder: Differences between subtypes. Psychiatry and Clinical Neurosciences, 66, 285-291. doi:10.1111/j.1440-1819.2012.02340.x

Watson, D., Clark, L. A., \& Carey, G. (1988a). Positive and negative affectivity and their relation to anxiety and depressive disorders. Journal of Abnormal Psychology, 97, 346-353. doi:10.1037/0021-843X.97.3.346

Watson, D., Clark, L. A., \& Tellegen, A. (1988b). Development and validation of brief measures of positive and negative affect. The PANAS scale. Journal of Personality and Social Psychology, 54, 1063-1070.
Wei, S. M., Eisenberg, D. P., Kohn, P. D., Kippenhan, J. S., Kolachana, B. S., Weinberger, D. R., \& Berman, K. F. (2012). Brain-derived neurotrophic factor Val66Met polymorphism affects resting regional cerebral blood flow and functional connectivity differentially in women versus men. Journal of Neuroscience, 32, 7074-7081.

doi:10.1523/JNEUROSCI.5375-11.2012

White, H. R., Marmorstein, N. R., Crews, F. T., Bates, M. E., Mun, E. Y., \& Loeber, R. (2011). Associations between heavy drinking and changes in impulsive behavior among adolescent boys. Alcoholism: Clinical and Experimental Research, 35, 295-303.

doi:10.1111/j.1530-0277.2010.01345.x

Zimmerman, B. J. (2000). Self-efficacy: An essential motive to learn. Contemporary Educational Psychology, 25, 82-91.

doi:10.1006/ceps.1999.1016 